\title{
Front Matter: Volume 7677
}

, "Front Matter: Volume 7677," Proc. SPIE 7677, Fiber Optic Sensors and Applications VII, 767701 (11 June 2010); doi: 10.1117/12.867285

SDIE Event: SPIE Defense, Security, and Sensing, 2010, Orlando, Florida, United SPIE. States 


\title{
PROCEEDINGS OF SPIE
}

\section{Fiber Optic Sensors and Applications VII}

\author{
Alexis Mendez \\ Henry H. Du \\ Anbo Wang \\ Eric Udd \\ Stephen J. Mihailov \\ Editors
}

7-8 April 2010

Orlando, Florida, United States

Volume 7677 
The papers included in this volume were part of the technical conference cited on the cover and title page. Papers were selected and subject to review by the editors and conference program committee. Some conference presentations may not be available for publication. The papers published in these proceedings reflect the work and thoughts of the authors and are published herein as submitted. The publisher is not responsible for the validity of the information or for any outcomes resulting from reliance thereon.

Please use the following format to cite material from this book:

Author(s), "Title of Paper," in Fiber Optic Sensors and Applications VII, edited by Alexis Mendez, Henry H. Du, Anbo Wang, Eric Udd, Stephen J. Mihailov, Proceedings of SPIE Vol. 7677 (SPIE, Bellingham, WA, 2010) Article CID Number.

ISSN 0277-786X

ISBN 9780819481412

Published by

SPIE

P.O. Box 10, Bellingham, Washington $98227-0010$ USA

Telephone +1 3606763290 (Pacific Time) · Fax +1 3606471445

SPIE.org

Copyright (C) 2010, Society of Photo-Optical Instrumentation Engineers

Copying of material in this book for internal or personal use, or for the internal or personal use of specific clients, beyond the fair use provisions granted by the U.S. Copyright Law is authorized by SPIE subject to payment of copying fees. The Transactional Reporting Service base fee for this volume is $\$ 18.00$ per article (or portion thereof), which should be paid directly to the Copyright Clearance Center (CCC), 222 Rosewood Drive, Danvers, MA 01923. Payment may also be made electronically through CCC Online at copyright.com. Other copying for republication, resale, advertising or promotion, or any form of systematic or multiple reproduction of any material in this book is prohibited except with permission in writing from the publisher. The CCC fee code is 0277-786X/10/\$18.00.

Printed in the United States of America.

Publication of record for individual papers is online in the SPIE Digital Library.

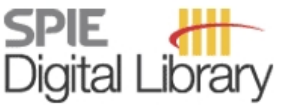

SPIEDigitalLibrary.org

Paper Numbering: Proceedings of SPIE follow an e-First publication model, with papers published first online and then in print and on CD-ROM. Papers are published as they are submitted and meet publication criteria. A unique, consistent, permanent citation identifier (CID) number is assigned to each article at the time of the first publication. Utilization of CIDs allows articles to be fully citable as soon they are published online, and connects the same identifier to all online, print, and electronic versions of the publication. SPIE uses a six-digit CID article numbering system in which:

- The first four digits correspond to the SPIE volume number.

- The last two digits indicate publication order within the volume using a Base 36 numbering system employing both numerals and letters. These two-number sets start with 00, 01, 02, 03, 04 , 05, 06, 07, 08, 09, OA, OB ... 0Z, followed by 10-1Z, 20-2Z, etc.

The CID number appears on each page of the manuscript. The complete citation is used on the first page, and an abbreviated version on subsequent pages. Numbers in the index correspond to the last two digits of the six-digit CID number. 


\section{Contents}

vii Conference Committee
xi Introduction

\section{SESSION $1 \quad$ DISTRIBUTED SENSORS, SENSING SYSTEMS, AND APPLICATIONS I}

767702 Pushing the limit of the distributed Brillouin sensors for the sensing length and the spatial resolution (Invited Paper) [7677-01]

X. Bao, H. Liang, Y. Dong, W. Li, Y. Li, L. Chen, Univ. of Ottawa (Canada)

767703 Distributed sensing for liquid leaks and spills (Invited Paper) [7677-02]

A. MacLean, J. McCormack, Solus Sensors Ltd. (United Kingdom); B. Culshaw, Univ. of Strathclyde (United Kingdom)

767704 Structural integrity and damage assessment of high performance arresting cable systems using an embedded distributed fiber optic sensor (EDIFOS) system (Invited Paper) [7677-03] E. A. Mendoza, C. Kempen, S. Sun, Y. Esterkin, J. Prohaska, Redondo Optics, Inc. (United States); D. Bentley, Cortland Cable Co. (United States); A. Glasgow, TMT Labs. (United States); R. Campbell, Applied Fiber (United States)

\section{SESSION 2 DISTRIBUTED SENSORS, SENSING SYSTEMS, AND APPLICATIONS II}

767707 Protection of critical infrastructure using fiber optic sensors embedded in technical textiles (Invited Paper) [7677-05]

K. Krebber, P. Lenke, S. Liehr, N. Noether, M. Wendt, A. Wosniok, BAM Federal Institute for Materials Research and Testing (Germany)

767708 Robust event classification for a fiber optic perimeter intrusion detection system using level crossing features and artificial neural networks [7677-06]

S. S. Mahmoud, J. Katsifolis, Future Fibre Technologies Pty Ltd. (Australia)

767709 Component field testing for SWPIDS: a shallow-water perimeter intrusion detection system [7677-07]

D. C. Burnett, D. Sheaffer, Jr., Sandia National Labs. (United States)

7677 OA Positioning method for dual Mach-Zehnder interferometric submarine cable security system [7677-08]

S. Xie, M. Zhang, S. Lai, Y. Liao, Tsinghua Univ. (China)

\section{SESSION 3 FIBER GRATING SENSORS I}

7677 OB Review of high-speed fiber optic grating sensor systems (Invited Paper) [7677-09]

E. Udd, Columbia Gorge Research (United States); J. Benterou, C. May, Lawrence Livermore National Lab. (United States); S. J. Mihailov, P. Lu, Communications Research Ctr. Canada (Canada) 
$76770 \mathrm{C}$ Structural health monitoring and impact detection for primary aircraft structures (Invited Paper) [7677-10]

E. Kosters, T. J. van Els, Technobis Fibre Technologies (Netherlands)

7677 OD A novel twin-core fiber grating sensor system and its applications [7677-11]

Y. Li, G. M. Bubel, D. J. Kudelko, M. F. Yan, M. J. Andrejco, OFS Fitel LLC (United States)

\section{SESSION 4 FIBER GRATING SENSORS II}

7677 OF Self-heated fiber Bragg grating sensors for cryogenic environments (Invited Paper)

[7677-13]

T. Chen, Univ. of Pittsburgh (United States); P. R. Swinehart, M. S. Maklad, Lake Shore

Cryotronics, Inc. (United States); M. P. Buric, K. P. Chen, Univ. of Pittsburgh (United States)

7677 OG High-temperature fiber Bragg grating sensors in microstructured fibers for harsh environment applications (Invited Paper) [7677-14]

Q. Wang, C. M. Jewart, Univ. of Pittsburgh (United States); J. Canning, The Univ. of Sydney (Australia); D. Grobnic, S. J. Mihailov, Communications Research Ctr. Canada (Canada); K. P. Chen, Univ. of Pittsburgh (United States)

$7677 \mathrm{OH} \quad$ Regenerated fiber Bragg gratings in non-hydrogen-loaded photosensitive fibers for high-temperature sensor networks [7677-15]

E. Lindner, Institute of Photonic Technology Jena (Germany); C. Chojetzki, Fibre Bragg Grating Sensors Technologies GmbH (Germany); M. Becker, S. Brückner, M. Rothhardt, H. Bartelt, Institute of Photonic Technology Jena (Germany)

7677 0l Liquid-level sensor based on fiber Bragg grating and carbon fiber composite diaphragm [7677-16]

D. Song, J. Zou, L.C. Pegasus (United States); Z. Wei, Stevens Institute of Technology (United States); H. Cui, L.C. Pegasus (United States)

7677 0J Analysis of temperature and strain changes profiles by using fiber Bragg grating sensors [7677-17]

M. Etezad, M. Kahrizi, K. Khorasani, Concordia Univ. (Canada)

\section{SESSION 5 FIBER GRATING SENSORS III}

7677 OK Research and application of fiber Bragg grating safety monitoring method for huge structures and equipments (Invited Paper) [7677-18]

D. Jiang, K. Che, C. Zhou, J. Huang, D. Fan, Wuhan Univ. of Technology (China)

$7677 \mathrm{OL}$ The design of strain rosette on fiber Bragg grating and carbon fiber laminate composite [7677-19]

D. Song, J. Zou, D. Li, H. Cui, L.C. Pegasus (United States)

7677 OM Nonintrusive FBG tube pressure transducers with high overpressure ability [7677-20]

I. F. Saxena, K. J. Hui, Intelligent Optical Systems, Inc. (United States) 
7677 ON What narrow-linewidth semiconductor lasers can do for defense and security? (Invited Paper) [7677-22]

M. Morin, S. Ayotte, C. Latrasse, M. Aubé, M. Poulin, Y. Painchaud, N. Gagnon, G. Lafrance, TeraXion Inc. (Canada)

767700 Optical Phase Lock Loop (OPLL) with tunable frequency offset for distributed optical sensing applications [7677-43]

V. Kupershmidt, F. Adams, Redfern Integrated Optics, Inc. (United States)

7677 OP Technologies of fiber fusion and fused device fabrication for sensing applications [7677-24] B. S. Wang, J. Stathis, Vytran LLC (United States)

$76770 Q \quad$ Implementation of fiber filters based on a macrobending high-bend loss fiber utilizing the Whispering Gallery mode effect [7677-25]

P. Wang, Y. Semenova, Q. WU, G. Farrell, Dublin Institute of Technology (Ireland)

\section{SESSION 7 PHYSICAL PARAMETER SENSORS AND APPLICATIONS}

7677 OR Review on developments in fiber optical sensors and applications [7677-26] K. K. K. Annamdas, Univ. of Miami (United States); V. G. M. Annamdas, Jawaharlal Nehru Technological Univ. (India)

7677 OS In situ dynamic measuring system to measure the vibratory and translational displacement of the airfoil modes of a combustion turbine compressor vane via an optical noncontact method (Invited Paper) [7677-27]

E. V. Diatzikis, M. Tartibi, M. Twerdochlib, Siemens Energy, Inc. (United States)

7677 OT Intrinsic Fabry-Pérot interferometric (IFPI) fiber pressure sensor [7677-28]

C. Ma, Virginia Polytechnic Institute and State Univ. (United States); N. Wang, China Univ. of Petroleum (China); E. M. Lally, A. Wang, Virginia Polytechnic Institute and State Univ. (United States)

7677 OU Chiral fiber sensors [7677-29]

V. I. Kopp, V. M. Churikov, J. Singer, D. Neugroschl, Chiral Photonics, Inc. (United States); A. Z. Genack, Chiral Photonics, Inc. (United States) and Queens College, CUNY (United States)

\section{SESSION $8 \quad$ ACOUSTIC SENSORS}

7677 OW Dynamic test of an acoustic/pressure sensor with precise cavity length control [7677-31] W. Wang, N. Wu, Y. Tian, C. Guthy, X. Wang, C. Niezrecki, Univ. of Massachusetts Lowell (United States)

7677 OX Theoretical analysis of a novel ultrasound generator on an optical fiber tip [7677-32] N. Wu, W. Wang, Y. Tian, C. Guthy, X. Wang, Univ. of Massachusetts Lowell (United States) 
7677 OY Simulation of a novel ultrasound generator-receiver on a single optical fiber [7677-33] X. Wang, Univ. of Massachusetts Lowell (United States); C. Liu, Univ. of Connecticut (United States); N. Wu, W. Wang, C. Guthy, Y. Tian, Univ. of Massachusetts Lowell (United States); C. Cao, Univ. of Connecticut (United States)

\section{SESSION 9 PHOTONIC CRYSTAL FIBERS AND SENSORS}

$767710 \quad$ PCF with immobilized silver nanoparticles as an optofluidic SERS sensing platform [7677-34] Y. Han, S. Tan, M. K. Khaing Oo, H. H. Du, Stevens Institute of Technology (United States)

767711 Mode coupling in photonic crystal fiber using long-period gratings for enhanced overlap of evanescent field [7677-36]

Z. He, Stevens Institute of Technology (United States); Y. Zhu, Northwestern Univ. (United States); J. Kaňka, Institute of Photonics and Electronics (Czech Republic); D. J. Trevor, OFS Labs. (United States); H. Du, Stevens Institute of Technology (United States)

767713 Frequency stabilization of a $2.05-\mu \mathrm{m}$ laser using hollow-core fiber $\mathrm{CO}_{2}$ frequency reference cell [7677-38]

P. Meras, I. Y. Poberezhskiy, D. H. Chang, G. D. Spiers, Jet Propulsion Lab. (United States)

767714 Monitoring the gaps between the platform screen doors and the doors of subway train based on optical time domain reflectrometer [7677-39]

H. Zhang, L.C. Pegasus (United States); Z. Wei, Stevens Institute of Technology (United States); P. Wang, New York Univ. Polytechnic Institute (United States); L. Fan, L. Guan, Q. Zhao, Stevens Institute of Technology (United States); H.-L. Cui, New York Univ. Polytechnic Institute (United States)

767715 Improvement of the accuracy of the aircraft center of gravity by employing optical fiber Bragg grating technology [7677-40]

H. Zhang, L.C. Pegasus (United States); P. Wang, New York Univ. Polytechnic Institute (United States); L. Fan, L. Guan, Q. Zhao, Stevens Institute of Technology (United States); H.-L. Cui, New York Univ. Polytechnic Institute (United States)

767716 Novel signal demodulation technique to estimate the amount of chirp in fiber Bragg gratings [7677-41]

M. Kondiparthi, Indian Institute of Science (India)

767717 High sensitive static fiber Bragg grating strain sensing using lasers locked to relative frequency reference [7677-42]

M. Kondiparthi, Indian Institute of Science (India)

Author Index 


\title{
Conference Committee
}

\author{
Symposium Chair
}

Michael T. Eismann, Air Force Research Laboratory (United States)

Symposium Cochair

William Jeffrey, HRL Laboratories, LLC (United States)

Conference Chairs

Alexis Mendez, MCH Engineering LLC (United States)

Henry H. Du, Stevens Institute of Technology (United States)

Anbo Wang, Virginia Polytechnic Institute and State University (United States)

Conference Cochairs

Eric Udd, Columbia Gorge Research (United States)

Stephen J. Mihailov, Communications Research Center Canada (Canada)

Program Committee

Christopher S. Baldwin, Aither Engineering, Inc. (United States)

Jerry J. Benterou, Lawrence Livermore National Laboratory (United States)

Eric A. Bergles, BaySpec, Inc. (United States)

Jeff Bush, Optiphase, Inc. (United States)

Steven D. Christesen, U.S. Army Edgewood Chemical Biological Center (United States)

Brian Culshaw, University of Strathclyde (United Kingdom)

Wolfgang Ecke, IPHT Jena (Germany)

Abdessamad Elyamani, Northrop Grumman Corporation

(United States)

Yoel Fink, Massachusetts Institute of Technology (United States)

Eric Goldner, U.S. Sensor Systems Inc. (United States)

Tom W. Graver, Micron Optics, Inc. (United States)

Ming Han, University of Nebraska, Lincoln (United States)

Hajime Haneda, National Institute for Materials Science (Japan)

Kazuo Hotate, The University of Tokyo (Japan)

Jirí Kaňka, Institute of Photonics and Electronics (Czech Republic)

Victor I. Kopp, Chiral Photonics, Inc. (United States)

Steven T. Kreger, Luna Innovations Inc. (United States) 
David A. Krohn, Light Wave Venture Consulting, LLC (United States)

Paul Lefebvre, LxDATA (Canada)

Thomas D. Monte, KVH Industries (United States)

Gary Pickrell, Virginia Polytechnic Institute and State University (United States)

Glen A. Sanders, Honeywell Technology (United States)

Svetlana A. Sukhishvili, Stevens Institute of Technology (United States)

Dennis J. Trevor, OFS Fitel, LLC (United States)

Xingwei Wang, University of Massachusetts Lowell (United States)

Younan Xia, University of Washington (United States)

Hai Xiao, Missouri University of Science and Technology (United States)

\section{Session Chairs}

1 Distributed Sensors, Sensing Systems, and Applications I

Alexis Mendez, MCH Engineering LLC (United States)

Katerina Krebber, Bundesanstalt für Materialforschung und -prüfung (Germany)

2 Distributed Sensors, Sensing Systems, and Applications II

Brian Culshaw, University of Strathclyde (United Kingdom)

Xiaoyi Bao, University of Ottawa (Canada)

3 Fiber Grating Sensors I

Stephen J. Mihailov, Communications Research Center Canada (Canada)

Kevin P. Chen, University of Pittsburgh (United States)

$4 \quad$ Fiber Grating Sensors II

Eric Udd, Columbia Gorge Research (United States)

Jerry J. Benterou, Lawrence Livermore National Laboratory (United States)

$5 \quad$ Fiber Grating Sensors III

Anbo Wang, Virginia Polytechnic Institute and State University (United States)

Edgar A. Mendoza, Redondo Optics, Inc. (United States)

6 Specialty Fibers and Components for Sensing

Hai Xiao, Missouri University of Science and Technology (United States)

Alexis Mendez, MCH Engineering LLC (United States)

$7 \quad$ Physical Parameter Sensors and Applications

Steven T. Kreger, Luna Innovations Inc. (United States)

Christopher S. Baldwin, Aither Engineering, Inc. (United States) 
8 Acoustic Sensors

Henry H. Du, Stevens Institute of Technology (United States)

9 Photonic Crystal Fibers and Sensors

Henry H. Du, Stevens Institute of Technology (United States)

Gary Pickrell, Virginia Polytechnic Institute and State University (United States) 
Downloaded From: https://www.spiedigitallibrary.org/conference-proceedings-of-spie on 26 Apr 2023

Terms of Use: https://www.spiedigitallibrary.org/terms-of-use 


\section{Introduction}

SPIE has been sponsoring conferences on fiber optic sensor technology for over 30 years, and the Fiber Optic Sensors and Applications VII conference continues this tradition. This conference combines the former Fiber Optic Sensors and Applications, Sensors for Harsh Environments, and Photonic Crystals and Photonic Crystal Fibers for Sensing conferences into a single major fiber optic sensor conference that covers all aspects of fiber optic sensor technology, for both civil and defense applications.

Major R\&D efforts in fiber optic sensor technology have been conducted since the mid 1970s, which have led to the development, among many others, of optic acoustic sensors based on the Mach-Zehnder interferometer; fiber rotation gyro (FOG) sensors based on the Sagnac interferometer; discrete point sensors based on Fabry-Perot and fiber Bragg gratings; as well as distributed sensing techniques based on Rayleigh, Raman and Brillouin scattering techniques. Today, fiber optic sensors enjoy widespread use in a broad variety of applications and fields ranging from structural sensing and health monitoring of composites and structures in civil and aeronautic areas; to downhole pressure and temperature sensors for oil and gas reservoir monitoring; to high voltage and high current sensing systems for the power industry-to name just a few. However, new components and technology are continually being developed to support enhancement and extensions of existing fiber optic sensor technology, as well as to allow totally new innovations. New innovations-such as photonic crystalswhich offer the prospect of new highly efficient light sources as well as the potential for much higher levels of performance.

Given the unique optical properties of Photonic Crystal Fibers (PCF) coupled with the development of new and improved fabrication techniques and availability of high-quality photonic bandgap crystals, has fueled the global interest in their theoretical and experimental studies. The optical properties such as bandgap and light propagation characteristics of photonic bandgap crystals and PCFs can be manipulated by structural design and defect engineering. These properties can also be altered by external stimuli that can be thermal, optical, electrical, magnetic, chemical, biological, and nuclear, etc. The great potential of photonic bandgap crystals and PCF has been well-recognized for a variety of applications.

The overall result has been a continuing revitalization of the fiber optic sensor field that is apparent in the papers that are contained in these proceedings.

Alexis Mendez

Henry H. Du

Anbo Wang

Eric Udd

Stephen J. Mihailov 
Downloaded From: https://www.spiedigitallibrary.org/conference-proceedings-of-spie on 26 Apr 2023

Terms of Use: https://www.spiedigitallibrary.org/terms-of-use 